\title{
DODAWANIE OTUCHY JAKO FORMA WZMOCNIENIA LUDZKOŚCI NIE TYLKO W CZASIE PANDEMII. MIĘDZYGENERACYJNA TRANSMISJA PRZESŁANIA WINCENTEGO KADŁUBKA
}

\author{
Offering Reassurance as a Form of Strengthening Humanity Not Only \\ during a Pandemic. The Inter-Generational Transmission of Wincenty \\ Kadłubek’s Message
}

S u m m a r y: Master Wincenty (ca. 1150-1223), who has been known as Kadłubek since the $15^{\text {th }}$ century, was an unquestionable ally of mankind and especially of Poles. In his work entitled Magistrii Vincentii Chronicon Polonorum he encouraged his readers not to neglect reassurance and to seek it wherever possible. He also advised people to try to enjoy offering reassurance to others and to lead a good life connected with faith in God, which in his belief constitutes the most reliable "safeguard of your happiness". This article aims to provide answers to several questions (and at the same time to solve a number of related research problems), How does Wincenty perceive reassurance and what significance does he attribute to offering it to other people? What advice does he give on not losing but gaining reassurance and on offering reassurance to others? What factors in his belief constitute stumbling blocks in the process of drawing reassurance for oneself and how to protect oneself against them (i.e., how to prevent their occurrence and how to overcome them)? The use of hermeneutic methods in studying the problems of providing reassurance as a social skill, an element that is very conspicuous in Master Wincenty's literary output, seems well justified, considering the cognitive and noetic significance of the research subject.

Ke y w o r d s: providing reassurance, gaining reassurance, mood, hope, inter-generation dialogue, pandemic

${ }^{1}$ Dr hab. Alicja Żywczok, prof. UŚ - Uniwersytet Śląski, Wydział Nauk Społecznych, Instytut Pedagogiki. Adres do korespondencji: ul. Michała Grażyńskiego 53, 40-126 Katowice; e-maile: alicjazyw@wp.pl, alicja.zywczok@us.edu.pl. 


\section{Wprowadzenie}

Do tych, którzy swą biografią zaświadczyli o postawie miłości bliźniego, przejawiającej się między innymi w dodawaniu ludziom (zarówno ówczesnym, jak i współczesnym) otuchy, daje się z pewnością zaliczyć biskupa krakowskiego, błogosławionego Wincentego Kadłubka². Jako niewątpliwy sprzymierzeniec ludzkości (w tym przede wszystkim Polaków), nie szczędził słów otuchy, pokrzepienia w trudnych chwilach, zachęcał do nietracenia i nabierania otuchy, a zwłaszcza do czerpania przyjemności z dodawania jej innym ludziom. Zalecał również prowadzenie dobrego życia związanego z głęboką wiarą w Boga, którą uznawał za najpewniejszą „strażniczkę szczęścia”.

O ponadczasowym charakterze myśli Wincentego Kadłubka zadecydowało przede wszystkim wyraźne jej zakorzenienie w nauce katolickiej, zapewniającej dziedzictwu kulturowemu stały fundament filozoficzno-teologiczny. Dzięki takim podwalinom wymowa dzieł nawet średniowiecznych okazuje się wielowiekowo aktualna ${ }^{3}$. Ich autorzy bowiem usiłowali zapobiec zatraceniu tożsamości religijnej i narodowej, a w życiu zbiorowym przywrócić troskę o dobro wspólne. Kontynuatorzy takiej tradycji z pewnością doceniają jej znaczenie społeczne i kulturowe, jednak uznanie dla osiągnięć znakomitych poprzedników, takich jak Wincenty Kadłubek, powinno być w XXI wieku wyrażane powszechniej.

Zanim usytuuję dokonania Mistrza Wincentego w okresie historycznym, w którym przyszło mu rozwinąć swą twórczą działalność, warto, jak sądzę, przeanalizować treść oryginalnego, staropolskiego pojęcia otuchy (mimo proweniencji związanej

${ }^{2}$ Wincenty urodził się około 1150 roku w miejscowości Karwów bądź Kargów, a zmarł w 1223 w Brzeźnicy, od XV wieku zwano go Kadłubkiem. To pierwszy polski kronikarz, myśliciel, kancelista, kapelan nadworny Kazimierza II Sprawiedliwego, człowiek gruntownie wykształcony (w Paryżu zdobył stopień magistra, tj. mistrza), który pochodził z możnego rodu małopolskiego. W schyłkowym okresie swego życia, pragnąc skoncentrować się na tworzeniu kroniki, w roku 1218 osiadł w klasztorze cystersów w Jędrzejowie kieleckim, pierwotnie noszącym nazwę Brzeźnicy. W XVIII wieku ogłoszono go błogosławionym. Zob. Słownik przewodnik filozoficzny. Osoby - problemy - terminy, red. Andrzej Maryniarczyk, Piotr Jaroszyński, Henryk Kiereś, Zofia Zdybicka (Lublin: Polskie Towarzystwo Tomasza z Akwinu, 2012), 146-147; Marzena Matla-Kozłowska, „Wstęp do Kroniki polskiej Mistrza Wincentego Kadłubka”. W: Mistrz Wincenty Kadłubek, Kronika polska, red. Stanisław Sierpowski (Wrocław: Zakład Narodowy im. Ossolińskich, 1996), 6, 7, 10; Brygida Kürbis, „Przedmowa”. W: Myśli i nauki Mistrza Wincentego zwanego Kadłubkiem, zbiór i tłum. Brygida Kürbis (Warszawa: Państwowy Instytut Wydawniczy, 1980), 10; Krzysztof R. Prokop, Wincenty Kadłubek (Kraków: Wydawnictwo WAM, 2005), 14, 45-49. Por. Katarzyna Chmielewska, „Uczeni w średniowiecznych klasztorach. Wykształceni zakonnicy - w relacjach kronikarskich”. W: Uczeni $z$ odległej i nieodległej przeszłości. Rekonstrukcje, interpretacje, refleksje, red. Alicja Żywczok, Małgorzata Kitlińska-Król (Katowice: Wydawnictwo Uniwersytetu Śląskiego, 2019), 35-46. Por. Marian Plezia, „Mistrz Wincenty zwany Kadłubkiem". W: Pisarze staropolscy, sylwetki, t. 1, red. Stanisław Grzeszczuk (Warszawa: Wiedza Powszechna, 1991), 93-131. Por. Roman Grodecki, „Mistrz Wincenty, biskup krakowski (zarys biograficzny)”. Rocznik Krakowski 19 (1923): 30-61. Por. Paweł Jasienica, Trzej kronikarze (Warszawa: „Czytelnik", 1992), 315-411. Por. Klemens Świżek, Błogosławiony Wincenty Kadłubek. Życie - kult - modlitwy (Jędrzejów: Nowa Galicja, 1999).

${ }^{3}$ Zob. Janina Kostkiewicz, Kierunki i koncepcje pedagogiki katolickiej w Polsce 1918-1939 (Kraków: Impuls, 2013), 13. Zob. też Chrześcijańskie inspiracje w pedagogice, red. Janina Kostkiewicz (Kraków: WUJ, 2011). 
z odległą tradycją językową termin stosuje się do dziś, choć trzeba przyznać, że jego użycie jest znacznie rzadsze). Specjalistyczne słowniki i encyklopedie pedagogiczne, psychologiczne czy socjologiczne nie zawierają niestety wyjaśnienia tego terminu, więc posłużyłam się literaturą językoznawczą.

Jeśli ktoś nabrał otuchy lub jeśli człowiek bądź okoliczność dodały komuś otuchy, oznacza to, że odzyskał wiarę w pokonanie określonej trudności i poczuł się lepiej. Najczęstsze zastosowanie terminu „otucha” ukazują następujące zdania: „Chciałem zgnębionemu człowiekowi dodać jakoś otuchy”; „Przyjaciel wlał mi w serce otuchę do walki z chorobą”; „Żołnierze nie stracili otuchy”; „Warto nabrać otuchy przed zmierzeniem się z tą sytuacją”; „Nagle uśmiechnął się, jakby wstąpiła w niego otucha”; „Nie chcę, by opuściła ją wszelka otucha”. Wśród terminów synonimicznych podaje się najczęściej: „nadzieję"5, „ufność”, „optymizm”, daje się dostrzec również bliskość semantyczną „otuchy” $\mathrm{z}$ „podniesieniem na duchu” oraz „poprawą nastroju”.

Znaczenie kategorii otuchy w naukach społecznych (zwłaszcza w pedagogice, psychologii, socjologii), humanistycznych i medycznych trudno przecenić. Jej wyraźne usytuowanie w subdyscyplinach pedagogicznych: pedagogice ogólnej, teorii wychowania, historii wychowania (i historii myśli pedagogicznej), a także w pedagogice kultury potwierdza związek tej kategorii nie tylko z bogatą tradycją pedagogiczną, lecz także ze współczesnymi teoretycznymi i prakseologicznymi osiągnięciami w tym zakresie. Nietrudno dostrzec również łączność podjętej problematyki z interdyscyplinarnym obszarem poznania określanym jako pedagogika filozoficzna, filozofia wychowania, etyka pedagogiczna oraz biografistyka. Gdy dziś rozpatruje się dodawanie otuchy jako typ oddziaływania różnych podmiotów

${ }^{4}$ Zob. Inny słownik języka polskiego PWN. A-Ó, red. Mirosław Bańko (Warszawa: WN PWN, 2017), 1205.

${ }^{5}$ Nadzieja - typ pozytywnego nastawienia intelektualnego i emocjonalnego do tego, co ma nastąpić; ludzkie oczekiwanie, że będzie lepiej niż dotychczas, ponieważ zrealizują się pragnienia, dążenia, cele bądź uda się podjąć określone wyzwania. Nadzieja (wiara i miłość) należy do głównych cnót chrześcijańskich. W psychologii - złożona emocja pozytywna (w poznawczo-strukturalnej teorii emocji nadzieja to jedna z tzw. emocji prospektywnych, czyli skierowanych na przyszłość). Zob. Ewa Trzebińska, Psychologia pozytywna (Warszawa: Wydawnictwa Akademickie i Profesjonalne, 2008), 96-97; Józef Kozielecki, Psychologia nadziei (Warszawa: Wydawnictwo Akademickie „Żak”, 2006), 54; Alicja Żywczok, Ku afirmacji życia. Pedagogiczne podstawy pomyślnej egzystencji (Katowice: Wydawnictwo Uniwersytetu Śląskiego, 2011), 343, 437-443.

${ }^{6}$ Zob. Witold Cienkowski, Praktyczny słownik wyrazów bliskoznacznych (Warszawa: Polska Oficyna Wydawnicza „BGW”, 1993), 162.

${ }^{7}$ Nastrój - nieintencjonalny stan psychiki człowieka, mający charakter procesów „rozlanych”. Rodzi się on w wyniku nie tylko przeżywania powtarzających się emocji o dużej sile, lecz także wskutek zmiany stanów neurohormonalnych i biochemicznych organizmu. Istotne różnice między emocją a nastrojem dotyczą: 1. Czasu trwania (emocje to epizody trwające zazwyczaj od kilku sekund do kilku minut, natomiast nastrój może trwać wiele godzin, a nawet dni i często ma nieuchwytny początek i koniec). 2. Intensywności (emocje mogą się ujawnić w znacznej intensywności, nastrojowi zaś przypisuje się umiarkowane nasilenie, mające czasami „falujący” przebieg. 3. Zróżnicowania (nastrój jest stanem mniej zróżnicowanym, o cechach bardziej globalnych niż emocja). Zob. Teresa Borowska, Emocje dzieci i młodzieży. Zasoby - rozwijanie (Katowice: Wydawnictwo Uniwersytetu Śląskiego, 2006), 12; Żywczok, Ku, 500. Por. Władysław Łosiak, Psychologia emocji (Warszawa: Wydawnictwa Akademickie i Profesjonalne, 2007). 
wychowujących: rodzica, wychowawcy, nauczyciela, opiekuna, asystenta rodziny czy animatora, analizowana problematyka może okazać się istotna również w rozwoju pedagogiki społecznej, pedagogiki rodziny, pedagogiki przedszkolnej, pedagogiki szkolnej (w tym pedagogiki szkoły wyższej), andragogiki, a także pedagogiki opiekuńczej i pedagogiki specjalnej. W każdej grupie wiekowej i w każdym środowisku wychowawczym potrzebni, wręcz niezastąpieni, okazują się ludzie potrafiący dodać innym otuchy i w ten sposób ukierunkowujący ich na wybór inklinacji pozytywnej. Dodawanie otuchy stanowi cenną umiejętność społeczną, zwłaszcza przedstawicieli określonych profesji (na przykład pedagoga, psychologa i psychoterapeuty, pracownika socjalnego). Należy do umiejętności i postaw poszukiwanych także wśród członków innych grup zawodowych, choćby lekarzy, pielęgniarek czy ratowników medycznych, a chętnie realizowanych między innymi przez duchowieństwo.

Dodawanie otuchy (wyłącznie do postępowania właściwego pod względem etycznym i moralnym) nie stanowi jednak prostej czynności człowieka pomagającego bądź wspierającego innych ludzi. Analiza dzieła średniowiecznego myśliciela Magistrii Vincentii Chronicon Polonorum ${ }^{8}$ pozwala poszukiwać genezy tej wyjątkowej umiejętności w osobowości nieco charyzmatycznej, a przy tym uosabiającej takie cnoty chrześcijańskie, jak prawość, uczciwość, sprawiedliwość, życzliwość, bezinteresowność, wielkoduszność, roztropność, dzielność.

Warto podać choć kilka faktów dziejowych, by naświetlić kontekst analiz oraz skonstruować podwalinę rzetelnej interpretacji Kroniki polskiej - znakomitego, napisanego po łacinie, dzieła polskiej historiografii. Stulecie, w którym Wincenty narodził się i wykształcił, określa się mianem „renesansu XII wieku”, ponieważ nastąpił wówczas imponujący rozkwit kultury przejawiający się: korzystaniem z dorobku starożytności, zapoczątkowaniem uniwersytetów, powstawaniem szkół i bibliotek, rozwojem literatury i nauki (między innymi filozofii czy prawa). Z kolei przemiany polityczne doprowadziły do umocnienia władzy papieskiej, co ujawniają pontyfikaty Aleksandra III i Innocentego III. Za życia Wincentego doszło do rozbicia dzielnicowego i osłabienia rodu Piastów, zaś w cesarstwie rzymskim nasiliły się niepokoje społeczne związane $\mathrm{z}$ bezpardonową walką o władzę 9 .

Za przedmiot badań zaprezentowanych w niniejszym artykule przyjęłam Mistrza Wincentego postrzeganie dodawania otuchy (jako formy wzmocnienia ludzkości)

8 „Magistrii Vincentii Chronicon Polonorum”. W: Monumenta Poloniae Historica, nova series, t. 11, red. Marian Plezia (Kraków: Polska Akademia Umiejętności, 1994).

9 Zob. Matla-Kozłowska, „Wstęp”, 9; Henryk Samsonowicz, „Sytuacja polityczna Polski w czasach Wincentego". W: Onus Athlanteum. Studia nad Kroniką biskupa Wincentego, red. Andrzej Dąbrówka, Witold Wojtowicz (Warszawa: Instytut Badań Literackich PAN Wydawnictwo, Stowarzyszenie „Pro Cultura Litteraria, 2009), 29. Por. Przemysław Wiszewski, „Polska w kronice Mistrza Wincentego. Ze studiów nad terminologią dzieła i hierarchiami wartości w Polsce pełnego średniowiecza”. W: Onus Athlanteum, 75-90. Por. Jerzy Wyrozumski, „Kraków i Małopolska w czasach Mistrza Wincentego Kadłubka”. W: Mistrz Wincenty Kadłubek. Człowiek i dzieło, pośmiertny kult i legenda, red. Krzysztof Prokop (Kraków: PAU, 2001), 13-19. Por. Janusz Bieniak, „Mistrz Wincenty w życiu politycznym Polski przełomu XII i XIII wieku”. W: Mistrz Wincenty Kadłubek, 21-48. 
w obliczu zagrożeń spowodowanych między innymi obecną pandemią. Niniejszy artykuł stanowi więc propozycję udzielenia odpowiedzi na kilka pytań (i zarazem rozwiązania problemów badawczych): jak Wincenty Kadłubek postrzega otuchę oraz jakie znaczenie przypisuje dodawaniu jej innym ludziom? Jakie przekazuje wskazówki odnośnie do nietracenia i nabierania otuchy oraz dodawania jej innym? Jakie czynniki stanowią, w jego przekonaniu, przeszkody w napełnianiu się otuchą oraz jak się przed nimi chronić (względnie jak im zapobiegać lub jak je pokonywać)? Jakie przesłanie myśliciela daje się sformułować w odniesieniu do ludzi cierpiących dziś z powodu pandemii? Pytania te wyznaczają zarazem teoretyczne (poznawcze) i praktyczne (utylitarne) cele niniejszych badań. Posłużenie się metodami hermeneutycznymi: pól semantycznych oraz interpretacji wstępnej, zasadniczej, skoordynowanej i kontekstowej ${ }^{10} \mathrm{w}$ badaniu problematyki dodawania otuchy jako cennej umiejętności społecznej, rozpoznanej w dorobku tego myśliciela, wydaje się uzasadnione, biorąc pod uwagę jej intencjonalne poznanie.

\section{Znaczenie społeczne i noetyczne dialogu międzygeneracyjnego ${ }^{11} \mathrm{w}$ okresie pandemii}

Założyłam, że dialog międzygeneracyjny to nie tylko dobry kontakt między przedstawicielami pokoleń żyjących, na przykład rodzicami i potomstwem czy dziadkami i wnukami, lecz także wymiana treści intelektualnych i duchowych między odległymi, biorąc pod uwagę przede wszystkim kryterium czasu, generacjami (na przykład współczesnymi i przeszłymi). Dialog słusznie wydaje się czymś więcej niż jednokierunkowa transmisja przekazu międzypokoleniowego, skłaniająca do odbioru określonych treści. Dwukierunkowy charakter dialogu dowodzi komunikacji między przedstawicielami pokoleń, nawet minionych. Na pytania, jakie poprzednicy stawiali w swych dziełach, mogą przecież z powodzeniem odpowiedzieć ich następcy. Z kolei ludzie współcześni, formułując problemy badawcze, próbują odnaleźć trafne rozwiązanie za pośrednictwem analizy dzieł poprzedników. Transmisja określonych treści intelektualnych skłania jednak do dialogu, niejako go zapoczątkowuje.

${ }^{10}$ Zob. Jean Grondin, Wprowadzenie do hermeneutyki filozoficznej, tłum. Leszek Łysień (Kraków: Wydawnictwo WAM, 2007); Antoni B. Stępień, Wstęp do filozofii (Lublin: Towarzystwo Naukowe Katolickiego Uniwersytetu Lubelskiego, 2001); Andrzej Przyłębski, Hermeneutyka. Od sztuki interpretacji do teorii i filozofii rozumienia (Poznań: Zysk i S-ka Wydawnictwo, 2019); Bogusław Milerski, Hermeneutyka pedagogiczna. Perspektywy pedagogiki religii (Warszawa: WN ChAT, 2011); Wartość i sens. Aksjologiczne aspekty teorii interpretacji, red. Andrzej Tyszczyk, Edward Fiały, Ryszard Zajączkowski (Lublin: Wydawnictwo Katolickiego Uniwersytetu Lubelskiego, 2003); Bartosz Brożek, Granice interpretacji (Kraków: Copernicus Center Press Sp. z o.o., 2020).

${ }^{11}$ Por. Więzi międzypokoleniowe w rodzinie i $w$ kulturze, red. Wojciech Świątkiewicz (Katowice: Studio Noa, Uniwersytet Śląski, 2012). 
Oprócz dostrzeżenia społecznego oraz kulturotwórczego znaczenia dialogu międzygeneracyjnego, warto zaakcentować jego znaczenie noetyczne (wyrażające się między innymi w dodawaniu otuchy potomnym). Podobieństwo ludzkich doświadczeń i przeżyć, na przykład emocjonalnych, niezależnie od okresu historycznego, w którym przyszło im żyć, umożliwia korzystanie z wypracowanych przez przodków wzorców radzenia sobie z problemami czy dylematami. Nawet jeśli powody problemów trapiących niegdyś (choćby w średniowieczu) ludzkość i sposoby ich rozwiązywania okazują się odmienne od dzisiejszych, ich przejawy i skutki były w różnych okresach bardzo podobne. Poprzednicy zasługują zatem na dobre zrozumienie także w XXI wieku i sądzę, że mogą na nie liczyć ze strony ludzi ceniących tradycję kulturową oraz wykazujących szacunek do historii jako nauki humanistycznej.

Konieczność zmierzenia się współcześnie z dotkliwym problemem - pandemią $^{12}$ wywołaną przez Covid-19 (ang. Coronavirus Disease 2019) ${ }^{13}$, powinna skłaniać ludzi do wzmacniania się dobrą radą przodków, a także ofiarowanym szczerym wsparciem. W zakresie przezwyciężania problemów zdrowotnych oraz wynikającego z nich czasem zachwiania równowagi psychicznej warto więc, zmniejszając ryzyko popełnienia błędu, korzystać z osiągnięć doświadczonych i zaufanych poprzedników, zwłaszcza ludzi, którzy przejawiali braterskie uczucia do rodaków bądź solidaryzowali się z ludzkością. Cenny przekaz noetyczny wydobyty (a nawet odkryty w dziełach przodków) z ich dzieł stanowi zarazem ofertę pomocy i wyzwanie dla współczesnych społeczności, by skuteczniej poradziły sobie z problemem, a przede wszystkim by nauczyły się zapobiegać podobnym zagrożeniom. Poszczególne części artykułu zawierają więc propozycje średniowiecznego myśliciela dotyczące nietracenia, nabierania, przywracania oraz dodawania otuchy kolejnym pokoleniom.

\section{Rozumienie specyfiki ludzkiego poczucia szczęścia - warunek nietracenia otuchy}

Mistrz Wincenty przypomina, że świadomość niedoskonałości człowieka rodzi w nim między innymi odczucie niepełnego szczęścia. Nakreślenie szczęścia pełnego jest możliwe tylko w wyobrażeniach, marzeniach, pragnieniach, dążeniach, celach

12 Pandemia to epidemia obejmująca swym zasięgiem bardzo duże obszary, np. kraj, kontynent, a nawet świat. Pandemiczny - w języku greckim pándēmos: „powszechny”, „należący do ogółu”. Do terminów bliskoznacznych pandemii zalicza się „endemię" i „epidemię”. Zob. Multimedialny Wielki słownik języka polskiego ze słownikiem wyrazów bliskoznacznych PWN (Warszawa: WN PWN, 2018). Wyniki badań dotyczące samopoczucia społeczeństwa polskiego w okresie pandemii (główne lęki, niepokoje, obawy) zawiera np. pozycja: Rafał Drozdowski, Maciej Frąckowiak, Marek Krajewski, Małgorzata Kubacka, Ariel Modrzyk, Łukasz Rogowski, Przemysław Rura, Agnieszka Stamm, Życie codzienne w czasach pandemii. Raport z pierwszego etapu badań (Poznań: Wydział Socjologii Uniwersytetu im. Adama Mickiewicza, 2020).

${ }^{13}$ Zakażenie tym wirusem może wywoływać ostrą chorobę zakaźną układu oddechowego, skutkującą wieloma powikłaniami, które zagrażają zdrowiu lub życiu pacjenta. 
wyznaczanych przez człowieka, lecz osiągnięcie poczucia pełni szczęścia w życiu doczesnym uważa on za niewykonalne. Realizacja ideału szczęśliwości następuje dopiero w życiu wiecznym (jako rezultat spełnienia wartości finalnej - zbawienia). Wyraził tę myśl w następującym fragmencie:

Chociaż może istnieć jakieś szczęście ludzkie, doskonałe być nie może. Nikt bowiem nie jest tak szczęśliwy, iżby pod jakimś względem nie wadził się ze swoim losem. Otóż my wprawdzie nie powinniśmy się chełpić szlachetnością naszego rodu, wytwornością ciała i umysłu, wysoką godnością, głośną sławą, obfitością wszelkich dostatków, bo to na nic się nie przyda; lecz nad tym z wielką pokorą zapłakać nam trzeba, że przy najświetniejszej pomyślności policzkuje nas jakiś osobliwy bicz smutku ${ }^{14}$.

Zazwyczaj bowiem w codziennej ludzkiej egzystencji, jak twierdzi kronikarz, doznanie radości bywa przytłumione smutkiem, a smutek osładzany radością ${ }^{15}$.

Naprzemienność pozytywnych i negatywnych przeżyć emocjonalnych sprawia, że doświadczenie szczęścia wydaje się zatarte, niepełne bądź krótkotrwałe. W zbliżeniu się ku ideałowi szczęścia niezbyt pomocne okazują się także: rodowód, piękno ciała, inteligencja, piastowane urzędy i zajmowane stanowiska, władza, zaszczyty, (czcza) sława czy dobra materialne. Nawet w komfortowej sytuacji człowiek doświadcza zwykle także pewnych emocji negatywnych, na przykład przykrości, więc względną stałość pozytywnej inklinacji życiowej może mu zapewnić tylko rozumienie specyfiki ludzkiego poczucia szczęścia, a przede wszystkim łączność z Bogiem (i to zarówno w chwilach radości, jak i smutku).

Jednocześnie przestrzega przed przyjmowaniem postawy cierpiętniczej (w nurcie psychoanalitycznym nazywanej masochistyczną) i dlatego zadaje pytanie retoryczne: „Któż bowiem mijałby całkowicie obojętnie winogrona lub figi zwisające po obu stronach ścieżki, zwłaszcza że same wpadają do jego ust? Godzi się więc rozweselić takimi przysmakami, a nie obarczać się ciężarem" ${ }^{16} \mathrm{z}$ powodu przyjemności, jakich niewątpliwie dostarczają. Nie zapominając o ambiwalencji kryjącej się w ludzkim poczuciu szczęścia, Wincenty wyraźnie zachęca do korzystania ze szczodrych darów, jakie Stwórca oferuje człowiekowi za pośrednictwem środowiska przyrodniczego. Cieszenie się smakiem, na przykład dojrzałych owoców, i ich obfitością stanowi więc naturalną ludzką reakcję, nie zaś grzeszną pokusę, jak w okresie średniowiecza twierdzili niektórzy.

Uogólniając, do głównych warunków nietracenia otuchy w trudnych chwilach należy, w przekonaniu Mistrza Wincentego, rozumienie niedoskonałości ludzkiego poczucia szczęścia, zwłaszcza naprzemienności pozytywnych i negatywnych przeżyć emocjonalnych. Nie bez znaczenia okazuje się również wystrzeganie się bądź rugowanie postawy cierpiętniczej (błędnie uznawanej za postawę chrześcijańską).

\footnotetext{
${ }^{14}$ Mistrz Wincenty Kadłubek, Kronika polska, 82.

${ }^{15}$ Zob. tamże, 83.

${ }^{16}$ Myśli i nauki Mistrza Wincentego, 21.
} 


\section{Apoteoza wartości, uosabianie cnót i respekt dla prawa - czynniki sprzyjające nabieraniu otuchy}

Jako sposób nabrania otuchy i osiągnięcia względnego szczęścia kronikarz subtelnie podpowiada czynienie tego, ,co rozum doradza, czego wymaga pożytek, czego żąda uczciwość, do czego nakłania miłość, co wreszcie nakazuje obowiązek prawa" ${ }^{17}$. Radzi więc ludziom dążącym do szczęścia jednoczesne uwzględnianie wymogów racjonalnych, aksjologicznych, jurydycznych, a także utylitarnych. Kronikarz, chcąc uchronić ludzkość przed bezrefleksyjnym uleganiem zwodniczym zasobom materialnym, pisze: „Często wszak winne grono kurczy się w rodzynek, często oliwa zamienia się w męty, często złoto wyradza się w żużel"18. W ten sposób odciąga ludzką uwagę od pseudobogactw, a kieruje ją na takie wartości, jak miłość, uczciwość, sprawiedliwość, wolność, prawda, odwaga, pokora, wierność, wyraźnie odróżniając je od wartości rzekomych (dziś - antywartości).

Zaleca również wysiłek związany z uosabianiem cnót, zwłaszcza nabożności, prawości, wielkoduszności, dobroci, życzliwości, wdzięczności, uczciwości, prawdomówności, roztropności, szczerości, przezorności, gościnności, hojności, cierpliwości, dzielności. Uważa ponadto, że dzięki cnocie ofiarności (inaczej poświęceniu, wyrzeczeniu) można zapobiec różnym rodzajom nieszczęść. Swój pogląd potwierdza w następującym fragmencie: „Nie obce jest cnocie z własną szkodą kłaść kres nieszczęściom publicznym"19. W przekonaniu filozofa ofiarność jako gotowość do narażenia własnego dobra (lub własnych dóbr) w imię realizacji wyższych wartości, stanowi cnotę zapobiegającą zwłaszcza problemom publicznym. Można ją jednak uznać, jak sądzę, także za środek profilaktyczny odnośnie do nieszczęść indywidualnych.

Mistrz Wincenty sugestywnie zachęca do przejawiania wrażliwości i do współodczuwania ze szczęśliwymi, lecz przede wszystkim z nieszczęśliwymi, pisząc: „Nie jest synem, kto bez bólu znosi nieszczęścia zbolałej matki” ${ }^{20}$, bowiem „ludzką jest rzeczą współczuć [...] cudzemu nieszczęściu”"21, tym bardziej więc nieszczęściu najbliższych, na przykład rodziców.

Reasumując, szacunek dla wartości (zwłaszcza moralnych, społecznych, duchowych) i prawa, uosabianie cnót moralnych, a także uwzględnianie kryterium użyteczności (względnie pożytku) w swych decyzjach i czynach stanowią, w przekonaniu Kadłubka, podstawowe czynniki sprzyjające nabieraniu otuchy oraz niepoddawaniu się pejoryzmowi i nihilizmowi.

\footnotetext{
17 Tamże, 101.

18 Mistrz Wincenty Kadłubek, Kronika polska, 15.

19 Myśli i nauki Mistrza Wincentego, 169.

20 Tamże.

${ }^{21}$ Mistrz Wincenty Kadłubek, Kronika polska, 87.
} 


\section{Okoliczności przywracania otuchy}

Przywołując wzór Kazimierza Sprawiedliwego, Mistrz Wincenty opisywał okoliczności rodzące powszechne zadowolenie, zatem mające swój udział również w przywracaniu otuchy. Oto ilustrujący to fragment:

Było zaś stałym jego zwyczajem obchodzenie uroczystości świętych. Gdy więc cały dzień świętego Floriana poświęcił Panu, spędzając go to na nabożeństwie, to na modlitwie, to na dziękczynieniu, nazajutrz wyprawił świetną biesiadę dla książąt, wielmożów [...]. Oprócz biesiady wiele powodów pobudzało ich do wesela: najpierw - odniesione [...] nad nieprzyjacioły tryumfy, po wtóre - [to, iż - B.K.] po tak niebezpiecznych trudach książę był zdrów i cały, po trzecie - tak jego własny, jak i przyjaciół bezpieczny pokój, po czwarte - świąteczna błogość [przeżywanego - B.K.] powodzenia. Nie brakło też milszego nad wszystkie rozkosze rozradowania najdostojniejszego księcia, co pobudzało wszystkich do tym większej ochoty i wesela ${ }^{22}$.

Z przekonaniem twierdzi także, że „Mniejszym nieszczęściem jest znosić ucisk jarzma w ojczyźnie niż ginąć pośród udręk wygnania"²3.

Szczęście pomnaża też pielgrzymowanie do miejsc kultu religijnego bądź spotkanie z ludźmi błogosławionymi, co zostało wyrażone następująco: „, [...] z wielką pobożnością [Bolesław Mieszkowic - I Chrobry - od autora/ki tekstu] wybiera się [...] w drogę do szczytu religijności, do ojca świętości i opiekuna, do błogosławionego Wojciecha, bezustannie prześladowanego przez Czechów, uszanowanie mu okazuje i z [...] zapałem cześć oddaje"24.

Uogólniając, w przywracaniu otuchy i stopniowemu napełnianiu się nią niebagatelne znaczenie mają zatem, w przekonaniu myśliciela, następujące czynniki:

- Uroczyste obchody rocznic ludzi uznanych przez Kościół za świętych i błogosławionych (zwłaszcza nabożeństwa, modlitwa dziękczynna w ich trakcie).

- Pielgrzymowanie do miejsc kultu religijnego bądź spotkanie z ludźmi wyróżniającymi się pobożnością.

- Zwycięstwo w bitwie odniesione nad nieprzyjaciółmi i wyprawienie na cześć zwycięzców uczty, podczas której atmosfera rozradowania głównego uczestnika (np. księcia) udziela się wszystkim biesiadnikom.

- Stan pokoju zapewniający międzynarodowe bezpieczeństwo.

- Przebywanie w ojczyźnie nawet, gdy trzeba znieść jarzmo niewoli.

- Dobre zdrowie fizyczne (w tym brak ran i okaleczeń) oraz samopoczucie psychiczne.

- Dodanie otuchy przygnębionym dzięki wspólnemu pokonywaniu przeciwności. Mistrz Wincenty zawarł w swym dziele wiele wskazówek odnośnie do radzenia sobie z nieszczęściami, na przykład wydarzeniami określanymi dziś jako traumatyczne

\footnotetext{
22 Tamże, 234-235.

${ }^{23}$ Myśli i nauki Mistrza Wincentego, 169.

${ }^{24}$ Mistrz Wincenty Kadłubek, Kronika polska, 51.
} 
(gdyż powodują traumę, to znaczy wywołują trwogę, smutek, przygnębienie, a nawet rozpacz). Oto pierwszy taki krzepiący fragment: „W położeniu samym przez się opłakanym rady potrzeba, nie łez, ponieważ ani płomienia nie gasi się płomieniem, ani smutku nie usuwa się smutkiem" ${ }^{25}$. Smucenie się przygnębiającymi faktami, zdaniem filozofa, pogłębia tylko stan smutku i nie przynosi ulgi cierpiącym, tym bardziej więc nie wspiera rozwiązania problemów.

Do ludzi strapionych i rozpaczających, czyli pogrążonych w chronicznym smutku, kieruje słowa otuchy: „Nie ma bardziej niedorzecznego sposobu tracenia rozumu, jak nie dbać wcale o zagojenie świeżej rany, jak nie chcieć - acz można wydobyć się z głębokiej topieli”26. W sytuacjach tzw. trudnych czy kryzysowych człowiek powinien, w przekonaniu myśliciela, otoczyć siebie troską, korzystając z danego mu przez Stwórcę wzorca miłości bliźniego. Oryginalne i skuteczne pocieszenie zawiera również kolejny fragment: „Za chmurą kryje się słońce, ale nigdy za chmurą nie gaśnie" 27 . Zacytowane stwierdzenie dowodzi, że smutek czy przygnębienie mają charakter krótkotrwały i choć pogrążonemu w nich człowiekowi wydają się długotrwałe, a nawet wieczne, słoneczne komponenty życia przeważają i nie pozwalają zdominować się przez „mrok” (będący metaforą inklinacji negatywnej).

W kwestii eliminacji trosk i zatroskania Kadłubek wypowiedział się w obszerniejszej narracji, przypominającej taką oto przypowieść: „Pewien człowiek, chcąc raz na zawsze usunąć żywicielki trosk, stopił w jedną bryłę swój dobytek i wrzucił do rzeki, mówiąc: "Przepadnijcie, nieszczęsne skarby! Zniszczę was, abyście wy mnie nie zniszczyły. Lżejsza bowiem jest strata mienia niż czasu"”28. Dobra materialne postrzega filozof jako przysparzające nieszczęść i niekorzystnie zmieniające charakter nie tyle posiadającego bogactwa (ich właściciela), ile kompulsywnie pomnażającego je człowieka. Stratę mienia uważa za niewielką w porównaniu $\mathrm{z}$ innymi stratami, na przykład stratą czasu (który można było wypełnić dobrymi czynami) czy utratą ludzi bliskich, więc stanowczo odradza zamartwianie się niedoborami finansowymi, którym człowiek zazwyczaj potrafi z powodzeniem zaradzić.

Zaznacza także, że ludziom potrzebującym pomocy służy choć drobne emocjonalne wsparcie znajomych, na przykład sąsiadów. „Ich przykłady pouczają [...], co każdy z nas Bogu winien, co sobie, co bliźniemu"29. Pozytywne wzory pomagają właściwie ukierunkować postępowanie oraz zmienić dotychczasowe, błędne przekonania o sobie, Stwórcy, innych ludziach i świecie, znacząco wpływając na biografię. Za najskuteczniejszych sprawców szczęścia uważa przyjaciół. W tym celu filozof przywołuje najlepsze wzorce przyjaźni, między innymi

\footnotetext{
${ }^{25}$ Myśli i nauki Mistrza Wincentego, 47.

${ }^{26}$ Tamże.

27 Tamże.

28 Tamże, 49.

29 Tamże, 69.
} 
uczniów Pitagorasa, którzy toczyli spór, chcąc umrzeć jeden za drugiego, a gdy żaden $\mathrm{z}$ nich nie oszczędzał siebie w obronie drugiego, przebaczono obydwóm ${ }^{30}$. Przyjaźń jawi się w tym fragmencie jako więź stanowiąca największą nagrodę ludzi zaprzyjaźnionych. Trudno bowiem o większą gratyfikację niż samo doznanie przyjaźni.

Oprócz tego Wincenty powiada wprost: „Wielką niegodziwością jest łajać w nieszczęściu tego, kogo szanowałeś, gdy dobrze mu się wiodło, bowiem pomyślność kojarzy przyjaciól, niedola wystawia ich na próbę"31, więc nie należy „Z nieszczęśliwych szydzić”32. Przyjaźń - nawiązana w sytuacjach obopólnej pomyślności weryfikuje się dopiero w chwilach zagrożenia czy nieszczęścia. Niepowodzenia przyjaciela nie powinny stać się wówczas przyczyną szydzenia z niego, lekceważenia czy karcenia go. Przyjaciele z powodzeniem rozwiewają poczucie osamotnienia, smutki, obawy i trwogi, dodają otuchy, która doskonale sprawdza się w pokonywaniu choroby fizycznej i psychicznej, a także w usuwaniu problemów i dylematów duchowych, a bliski związek z nimi staje się źródłem nadziei, poczucia sensu życia, a w rezultacie - poczucia szczęścia. Człowiek, który otacza się przychylnymi mu ludźmi, ma wiele powodów do zadowolenia, gdyż wówczas jego „ciężar przestaje być ciężarem”,33 a trud - trudem. „W drodze bowiem miłe towarzystwo jest jak wóz podróżny" ${ }^{34}$ - słusznie Mistrz Wincenty zauważył analogię obecności przyjaciół w podróży do wozu znacznie ułatwiającego przebycie długiej i uciążliwej drogi. Przyjaciel stanowi także najlepszy oręż w przypadku ataku nieprzyjaciela (jako wroga określonego człowieka lub wroga ojczyzny).

Pożądane cechy przyjaciela, względnie sprzymierzeńca, otacza uznaniem w następujących słowach: „Takiego przeto więc i wyszukać, i uprosić wypada, takiego wszyscy życzyć sobie powinni, który i w nieszczęściu byłby pociechą, i zachwianej sławy mocną podporą" ${ }^{35}$. Wierny przyjaciel (pozostający nim niezależnie od czyichś kolei losu) może uważać się za „znakomitego sprawcę [...] niezwykłego szczęścia”" ${ }^{36}$. Kronikarz podkreśla znaczenie miłości jako cechy (i postawy) ujmującej, czyli umożliwiającej pozyskanie przyjaciół i utożsamianej z tzw. dobrą wolą. Jako kryterium wyboru odpowiednich przyjaciół podpowiada upewnienie się co do uosabiania (przez potencjalnego przyjaciela), oprócz wspomnianej wierności, takich przymiotów charakteru, jak życzliwość, wielkoduszność, uczciwość, pobożność, szczerość, rozwaga, odwaga, ofiarność, skromność, cierpliwość. Odpowiedź na zadane przez Kadłubka (nieco metaforyczne) pytanie: „Jestże gdzieś

\footnotetext{
30 Mistrz Wincenty Kadłubek, Kronika polska, 119.

31 Myśli i nauki Mistrza Wincentego, 71.

32 Tamże.

33 Tamże, 69.

34 Tamże.

${ }^{35}$ Mistrz Wincenty Kadłubek, Kronika polska, 86.

36 Tamże.
} 
jakikolwiek ratunek dla rzeczy tak strzaskanych, dla szklanych ampułek, które znalazły się między młotem i kowadłem?" ${ }^{37}$, powinna, moim zdaniem, uwzględniać przede wszystkim termin „przyjaźń”. Kadłubek zwraca uwagę również na kolejną kwestię: bolesne doświadczenia czasem mobilizują ludzi do działania oraz do przezwyciężenia uciążliwości losu. Daje wyraz temu przekonaniu w słowach: „Trwoga sił przydała starości, a nogom skrzydel”"38. Cierpienie oraz determinacja do zmierzenia się z nim pozostaje więc istotnym czynnikiem motywującym i aktywizującym ludzi, nawet w senioralnym wieku.

Wincenty ukazał ponadto znaczenie wiary (i związanej z nią cnoty bogobojności) zarówno w przywracaniu i dodawaniu otuchy, jak i w genealogii ludzkiego szczęścia. Potwierdza to obszerny fragment:

Ona jedynie jest światłem w ciemności, promieniem słonecznym podczas pogody, ciszą wśród burzy, bezpieczeństwem pośród ciszy. Ona jedynie jest ostoją praw królewskich, koroną głowy królewskiej [...]. Gdy ona zgaśnie [...] wszelka wspólnota, wszelkie przymierze, wszelkie zobowiązanie, wszelka życzliwość, wszelka wreszcie i ozdoba, i moc cnót wszystkich słabnie i ginie. Bez wiary kto był kimś, staje się nikim, ponieważ sprawiedliwy żyje z wiary, która im dzisiaj rzadsza, tym jest milsza ${ }^{39}$.

W innym miejscu odniósł się do uczciwej wiary władcy następująco: „Nic zaś jaśniejszym światłem nie rozbłyska niż uczciwa wiara władcy. Nie ma też rzeczy, która by tak dalece nie była narażona na upadek, jak prawdziwa religia" ${ }^{30}$. Upadek wiary, a raczej jej osłabienie, biskup Wincenty uznaje za czynnik narażający na utratę także otuchy, mającej przecież swój znaczący wkład w budowanie postawy afirmacji życia.

\section{Podsumowanie}

Mistrz Wincenty jako uczony, a zarazem dostojnik Kościoła katolickiego, więc człowiek uduchowiony, nie pozostawał obojętny na zagrożenia zdrowotne (takie jak epidemie) i emocjonalno-duchowe (takie jak utrata otuchy) trapiące ludzkość. Zainteresowany, a nawet zatroskany psychofizyczną kondycją człowieka, nie pominął w swoim dziele - wyjątkowym osiągnięciu historiografii polskiej - ani problematyki zapobiegania utracie otuchy, ani też problematyki przywracania jej, nabierania otuchy (względnie napełniania się nią) i dodawania jej innym.

Rezultatem rozwiązania podanych we wprowadzeniu problemów badawczych są poniższe odpowiedzi.

\footnotetext{
${ }^{37}$ Myśli i nauki Mistrza Wincentego, 49.

38 Tamże, 53.

39 Tamże, 97.

${ }^{40}$ Mistrz Wincenty Kadłubek, Kronika polska, 51.
} 
1. Wincenty Kadłubek postrzega otuchę jako stan ludzkiej psychiki (dziś nazywany stanem emocjonalnym) pośredni między smutkiem a zadowoleniem, pewien etap na drodze prowadzącej do szczęścia. Znaczenie dodawania innym otuchy daje się odczytać w dziele filozofa dzięki deskrypcji przeciwieństw w postaci przyczyniania się do czyjejś apatii, lęku, niepokoju, trwogi, powodowania smutku, przygnębienia, wprawiania w nastrój beznadziejności (dziś nazywany obniżonym nastrojem) lub w rozpacz. Dodawanie otuchy wzmacnia nie tylko wspomaganego, lecz także w ten sposób pomagającego.

2. W przekonaniu Kadłubka istotnym warunkiem nietracenia otuchy (i niepoddawania się przygnębieniu, pesymizmowi czy nihilizmowi) okazuje się rozumienie specyfiki ludzkiego poczucia szczęścia, które w życiu doczesnym jest zawsze niepełne, więc niedoskonałe (doskonałe może stać się tylko w wieczności, po osiągnięciu zbawienia). Nie zapominając o dychotomii kryjącej się w ludzkiej egzystencji (związanej choćby z naprzemiennością chwil radości i smutku), wyraźnie zachęca do korzystania ze szczodrych darów Stwórcy, jakie oferuje człowiekowi między innymi bujna przyroda. Jednocześnie przestrzega przed przyjmowaniem postawy cierpiętniczej, którą Wincenty uznaje za niewłaściwą (niezgodną z wzorem chrześcijanina). Podstawowymi czynnikami sprzyjającymi nabieraniu otuchy są: szacunek dla wartości (takich jak miłość, uczciwość, sprawiedliwość, wolność, prawda, odwaga, pokora, wierność) i prawa oraz uosabianie cnót (zwłaszcza nabożności, prawości, wielkoduszności, dobroci, życzliwości, wdzięczności, uczciwości, prawdomówności, roztropności, szczerości, przezorności, gościnności, hojności, cierpliwości, dzielności, ofiarności). W tym celu myśliciel zachęca do przejawiania wrażliwości, która manifestuje się w umiejętności współodczuwania zarówno ze szczęśliwymi, jak i z nieszczęśliwymi.

W przywracaniu otuchy niebagatelne znaczenie mają także następujące czynniki: modlitwa dziękczynna; uroczyste obchody rocznic ludzi świętych i błogosławionych (zwłaszcza nabożeństwa); pielgrzymowanie do miejsc kultu religijnego bądź spotkanie z ludźmi wyróżniającymi się pobożnością; zwycięstwo w bitwie odniesione nad nieprzyjaciółmi i wyprawienie z tej okazji uczty, podczas której wśród biesiadników panuje atmosfera rozradowania; stan pokoju zapewniający międzynarodowe bezpieczeństwo; przebywanie w ojczyźnie nawet, gdy trzeba znieść jarzmo niewoli; dobre zdrowie fizyczne (w tym brak ran i okaleczeń) oraz samopoczucie psychiczne.

Jako dodanie otuchy przygnębionym filozof proponuje wpierw zakończenie lamentu, rozpamiętywania krzywd czy doznanych ciosów, a następnie staranie o „zagojenie ran” i przywrócenie pogodnego nastroju. Przypomina, że bolesne doświadczenia czasem mobilizują ludzi do samodzielnego przezwyciężenia uciążliwości losu. Oprócz tego przekonuje, że smutek czy przygnębienie mają często charakter krótkotrwały, ponieważ w naturze ludzkiej pozytywne komponenty 
emocjonalne przeważają. Ludzie tracący otuchę potrzebują natomiast choć drobnego psychicznego wsparcia bliźnich (na przykład sąsiadów), a przede wszystkim obecności niezawodnych przyjaciół wyróżniających się wieloma zaletami, zwłaszcza wiernością, wielkodusznością i uczciwością. Wincenty ukazał ponadto znaczenie wiary w Boga, zarówno w przywracaniu, jak i w dodawaniu otuchy.

3. Wskazując przeszkody w napełnianiu się otuchą, jednocześnie podpowiada, jak się przed nimi chronić (względnie jak je pokonywać). Dobra materialne postrzega filozof jako przysparzające nieszczęść i niekorzystnie zmieniające charakter nie tyle człowieka posiadającego bogactwa, ile bezrefleksyjnie pomnażającego je. Stratę mienia uważa za niewielką w porównaniu z innymi stratami, na przykład stratą czasu przeznaczonego na dobre uczynki/czyny czy z utratą ludzi darzonych miłością. Upadek, a raczej osłabienie wiary uznaje za czynnik narażający człowieka na utratę także otuchy. Prowadzenie dobrego życia związanego nieodłącznie z głęboką wiarą w Boga (którą uznawał za najpewniejszą „strażniczkę szczęścia”) najskuteczniej chroni przed utratą otuchy i przed wieloma jej przeciwieństwami. Nie pozostaje to, jak sądzę, bez znaczenia w procesie wychowania kolejnych pokoleń, których jakość życia będzie zależeć między innymi od umiejętności nabierania otuchy i dodawania jej innym ludziom.

4. Dokładna analiza i interpretacja dzieła Wincentego Kadłubka uprawnia do sformułowania przesłania tego myśliciela w postaci krótkiego apelu do każdego człowieka, zwłaszcza w okresie zmagania się z cierpieniem i niepokojem spowodowanymi pandemią: $\mathrm{W}$ trudnych chwilach nie trać otuchy. Nie obawiaj się nabierać otuchy do walki z przeciwnościami, takimi jak choroba. Czym prędzej przywróć otuchę sobie i otoczeniu, w którym przebywasz lub gościsz. Napełniaj się otuchą, gdy tylko jest ku temu konstruktywna sposobność. Dodając otuchy innym, stajesz się jednym z zarazem najszlachetniejszych i najszczęśliwszych ludzi. Rodzice i wychowawcy! Doskonalcie w dzieciach i młodzieży tę cenną umiejętność dodawania innym otuchy, a w przyszłości nie doznacie zawodu.

St r e s z c z e n i e: Mistrz Wincenty (ok. 1150-1223), od XV wieku zwany Kadłubkiem, jako niewątpliwy sprzymierzeniec ludzkości, a przede wszystkim Polaków, w swym dziele Magistrii Vincentii Chronicon Polonorum zachęcał do nietracenia i nabierania otuchy, a zwłaszcza do czerpania przyjemności z dodawania jej innym ludziom. Zalecał również prowadzenie dobrego życia związanego z wiarą w Boga, która w jego przekonaniu pozostaje najpewniejszą „strażniczką szczęścia”. Niniejszy artykuł stanowi więc propozycję udzielenia odpowiedzi na kilka pytań (i zarazem rozwiązania problemów badawczych), jak Wincenty Kadłubek postrzega otuchę oraz jakie znaczenie przypisuje dodawaniu jej innym ludziom? Jakie przekazuje wskazówki odnośnie do nietracenia i nabierania otuchy oraz dodawania jej innym? Jakie czynniki stanowią, jego zdaniem, przeszkody w napełnianiu się otuchą oraz jak się przed nimi chronić (to znaczy jak im zapobiegać oraz je pokonywać)? Posłużenie się metodami hermeneutycznymi w badaniu 
problematyki dodawania otuchy jako umiejętności społecznej, rozpoznanej w dorobku tego myśliciela, wydaje się uzasadnione, biorąc pod uwagę jej znaczenie poznawcze i noetyczne.

Słowa kluczowe: dodawanie otuchy, nabieranie otuchy, nastrój, nadzieja, dialog międzygeneracyjny, pandemia

\section{Bibliografia}

Bieniak, Janusz. „Mistrz Wincenty w życiu politycznym Polski przełomu XII i XIII wieku”. W: Mistrz Wincenty Kadłubek. Człowiek i dzieło, pośmiertny kult i legenda, red. Krzysztof R. Prokop, 21-48. Kraków: Polska Akademia Umiejętności, 2001.

Borowska, Teresa. Emocje dzieci i młodzieży. Zasoby - rozwijanie. Katowice: WUŚ, 2006.

Brożek, Bartosz. Granice interpretacji. Kraków: Copernicus Center Press Sp. z o.o., 2020.

Chmielewska, Katarzyna. „Uczeni w średniowiecznych klasztorach. Wykształceni zakonnicy - w relacjach kronikarskich". W: Uczeni z odległej i nieodległej przeszłości. Rekonstrukcje, interpretacje, refleksje, red. Alicja Żywczok, Małgorzata Kitlińska-Król, 35-46. Katowice: WUŚ, 2019.

Chrześcijańskie inspiracje w pedagogice, red. Janina Kostkiewicz. Kraków: WUJ, 2011.

Cienkowski, Witold. Praktyczny słownik wyrazów bliskoznacznych. Warszawa: Polska Oficyna Wydawnicza „BGW”, 1993.

Drozdowski, Rafał, Maciej Frąckowiak, Marek Krajewski, Małgorzata Kubacka, Ariel Modrzyk, Łukasz Rogowski, Przemysław Rura, Agnieszka Stamm. Życie codzienne w czasach pandemii. Raport z pierwszego etapu badań. Poznań: Wydział Socjologii Uniwersytetu im. Adama Mickiewicza, 2020.

Grodecki, Roman. „Mistrz Wincenty, biskup krakowski (zarys biograficzny)”. Rocznik Krakowski 19 (1923): 30-61.

Grondin, Jean. Wprowadzenie do hermeneutyki filozoficznej, tłum. Leszek Łysień. Kraków: Wydawnictwo WAM, 2007.

Inny słownik języka polskiego PWN. A-Ó, red. Mirosław Bańko. Warszawa: WN PWN, 2017.

Jasienica, Paweł. Trzej kronikarze. Warszawa: „Czytelnik”, 1992, 315-411.

Jaśtal, Jacek. Etyka i czas. Wariacje aretologiczne. Kraków: „Księgarnia Akademicka”, 2015.

Kostkiewicz, Janina. Kierunki i koncepcje pedagogiki katolickiej w Polsce 1918-1939. Kraków: Impuls, 2013.

Kozielecki, Józef. Psychologia nadziei. Warszawa: Wydawnictwo Akademickie „Żak”, 2006.

Kürbis, Brygida. „Przedmowa”. W: Myśli i nauki Mistrza Wincentego zwanego Kadłubkiem, zbiór i tłum. Brygida Kürbis, 6-17. Warszawa: Państwowy Instytut Wydawniczy, 1980.

Łosiak, Władysław. Psychologia emocji. Warszawa: Wydawnictwa Akademickie i Profesjonalne, 2007.

„Magistrii Vincentii Chronicon Polonorum”. W: Monumenta Poloniae Historica, nova series, t. 11, red. Marian Plezia. Kraków: Polska Akademia Umiejętności, 1994.

Matla-Kozłowska, Marzena. „Wstęp do Kroniki polskiej Mistrza Wincentego Kadłubka”. W: Mistrz Wincenty Kadłubek, Kronika polska, tłum. Brygida Kürbis, red. Stanisław Sierpowski, 5-13. Wrocław: Zakład Narodowy im. Ossolińskich, 1996.

Milerski, Bogusław. Hermeneutyka pedagogiczna. Perspektywy pedagogiki religii. Warszawa: WN ChAT, 2011.

Mistrz Wincenty Kadłubek. Kronika polska, tłum. Brygida Kürbis, red. Stanisław Sierpowski. Wrocław: Zakład Narodowy im. Ossolińskich, 1996.

Myśli i nauki Mistrza Wincentego zwanego Kadłubkiem, zbiór i tłum. Brygida Kürbis. Warszawa: Państwowy Instytut Wydawniczy, 1980. 
Plezia, Marian. „Mistrz Wincenty zwany Kadłubkiem”. W: Pisarze staropolscy, sylwetki, t. 1, red. Stanisław Grzeszczuk, 93-131. Warszawa: „Wiedza Powszechna”, 1991.

Prokop, Krzysztof R. Wincenty Kadłubek. Kraków: Wydawnictwo WAM, 2005.

Przyłębski, Andrzej. Hermeneutyka. Od sztuki interpretacji do teorii i filozofii rozumienia. Poznań: Zysk i S-ka Wydawnictwo, 2019.

Samsonowicz, Henryk. „Sytuacja polityczna Polski w czasach Wincentego”. W: Onus Athlanteum. Studia nad Kroniką biskupa Wincentego, red. Andrzej Dąbrówka, Witold Wojtowicz, 29-38. Warszawa: Instytut Badań Literackich PAN Wydawnictwo, Stowarzyszenie „Pro Cultura Litteraria”, 2009.

Stownik przewodnik filozoficzny. Osoby - problemy - terminy, red. Andrzej Maryniarczyk, Piotr Jaroszyński, Henryk Kiereś, Zofia Zdybicka. Lublin: Polskie Towarzystwo Tomasza z Akwinu, 2012.

Stępień, Antoni B. Wstęp do filozofii. Lublin: Towarzystwo Naukowe Katolickiego Uniwersytetu Lubelskiego, 2001.

Świżek, Klemens. Błogosławiony Wincenty Kadłubek. Życie - kult - modlitwy. Jędrzejów: Nowa Galicja, 1999.

Trzebińska, Ewa. Psychologia pozytywna. Warszawa: Wydawnictwa Akademickie i Profesjonalne, 2008. Wartość $i$ sens. Aksjologiczne aspekty teorii interpretacji, red. Andrzej Tyszczyk, Edward Fiały, Ryszard Zajączkowski. Lublin: Wydawnictwo Katolickiego Uniwersytetu Lubelskiego, 2003.

Wielki słownik języka polskiego ze słownikiem wyrazów bliskoznacznych PWN. Warszawa: WN PWN, 2018. Więzi międzypokoleniowe $w$ rodzinie i w kulturze, red. Wojciech Świątkiewicz. Katowice: Studio Noa, Uniwersytet Śląski, 2012.

Wiszewski, Przemysław. „Polska w kronice Mistrza Wincentego. Ze studiów nad terminologią dzieła i hierarchiami wartości w Polsce pełnego średniowiecza”. W: Onus Athlanteum. Studia nad Kronika biskupa Wincentego, red. Andrzej Dąbrówka, Witold Wojtowicz, 75-90. Warszawa: Instytut Badań Literackich PAN Wydawnictwo, Stowarzyszenie „Pro Cultura Litteraria”, 2009. Wyrozumski, Jerzy. „Kraków i Małopolska w czasach Mistrza Wincentego Kadłubka”. W: Mistrz Wincenty Kadłubek. Człowiek i dzieło, pośmiertny kult i legenda, red. Krzysztof R. Prokop, 13-19. Kraków: Polska Akademia Umiejętności, 2001.

Żywczok, Alicja. Ku afirmacji życia. Pedagogiczne podstawy pomyślnej egzystencji. Katowice: WUŚ, 2011. 